Article

\title{
Efficient Multifunctional Catalytic and Sensing Properties of Synthesized Ruthenium Oxide Nanoparticles
}

\author{
Ruby Phul ${ }^{1}$, Mohammad Perwez ${ }^{2}$, Jahangeer Ahmed ${ }^{3}$, Meryam Sardar ${ }^{2}$, \\ Saad M. Alshehri ${ }^{3}$, Norah Alhokbany ${ }^{3}$, Mohd A. Majeed Khan ${ }^{4}$ and Tokeer Ahmad ${ }^{1, *(D)}$ \\ 1 Nanochemistry Laboratory, Department of Chemistry, Jamia Millia Islamia, New Delhi 110025, India; \\ rubyphul@gmail.com \\ 2 Enzyme Technology Laboratory, Department of Biosciences, Jamia Millia Islamia, New Delhi 110025, India; \\ perwezmohammad@gmail.com (M.P.); msardar@jmi.ac.in (M.S.) \\ 3 Department of Chemistry, College of Science, King Saud University, Riyadh 11451, Saudi Arabia; \\ jahmed@ksu.edu.sa (J.A.); alshehri@ksu.edu.sa (S.M.A.); nhokbany@ksu.edu.sa (N.A.) \\ 4 King Abdullah Institute for Nanotechnology, King Saud University, Riyadh 11451, Saudi Arabia; \\ mmkhan@ksu.edu.sa \\ * Correspondence: tahmad3@jmi.ac.in; Tel.: +91-11-26981717 (ext. 3261); Fax: +91-11-26980229
}

Received: 23 June 2020; Accepted: 7 July 2020; Published: 13 July 2020

\begin{abstract}
Ruthenium oxide is one of the most active electrocatalyst for oxygen evolution (OER) and oxygen reduction reaction (ORR). Herein, we report simple wet chemical route to synthesize $\mathrm{RuO}_{2}$ nanoparticles at controlled temperature. The structural, morphological and surface area studies of the synthesized nanoparticles were conducted with X-ray diffraction, electron microscopy and BETsurface area studies. The bifunctional electrocatalytic performance of $\mathrm{RuO}_{2}$ nanoparticles was studied under different atmospheric conditions for OER and ORR, respectively, versus reversible hydrogen electrode (RHE) in alkaline medium. Low Tafel slopes of $\mathrm{RuO}_{2}$ nanoparticles were found to be $\sim 47$ and $\sim 49 \mathrm{mV} / \mathrm{dec}$ for OER and ORR, respectively, in oxygen saturated 0.5 M KOH system. Moreover, the catalytic activity of $\mathrm{RuO}_{2}$ nanoparticles was examined against the Horseradish peroxidase enzyme (HRP) at high temperature, and the nanoparticles were applied as a sensor for the detection of $\mathrm{H}_{2} \mathrm{O}_{2}$ in the solution.
\end{abstract}

Keywords: ruthenium oxide; nanoparticles; electrocatalysts; sensing

\section{Introduction}

The present generation is largely dependent on fossil fuelsto meet the present energy requirements-for instance, oil, coal, or natural gases. However, these energy demands fulfilled by these products directly affect the environment. The burning of fossil fuels leads up to the emissions of carbon dioxide gas (a greenhouse gas), which is affecting the world significantly through global warming, change in weather patterns and several other noteworthy geographical changes [1]. In addition, we know fossil fuels are nonrenewable resources, hence they will eventually deplete, so alternatives must be found. Therefore, the development of efficient, inexpensive and eco-friendly sources of energy has become a significant and crucial task for the researchers [2]. Scientists have investigated the use of renewable resources such as solar, wind, tidal, biomass, geothermal energy etc. The major research trend of today's era is the water-splitting phenomena for energy generation. Water splitting via electrocatalysis or photocatalysis is a clean, environmentally friendly and renewable source of energy for fuel cells, batteries and hydrogen generation [3-5]. In the presence of electro/photocatalyst, the water molecule splits into hydrogen and oxygen gas (i.e., $\mathrm{H}_{2} \mathrm{O} \rightarrow \mathrm{H}_{2}+1 / 2 \mathrm{O}_{2}$ ). The evolved 
hydrogen gas is used in fuel cells as a fuel which further reacts with $\mathrm{O}_{2}$ to produce an electric current. The evolved oxygen gas participates in the combustion reaction of fuel cells to generate power.

Forthe past few decades, researchers made headway in creating robust and efficient catalysts for the oxidation of water. Several noble metals viz. $\mathrm{Pt}, \mathrm{Ir}, \mathrm{Ru}$ and their oxide-based catalysts have been developed for oxidation-reduction reactions [6-8]. Various other earth-abundant metal-based catalysts such as $\mathrm{Mn}, \mathrm{Fe}, \mathrm{Co}, \mathrm{Cu}$ and $\mathrm{W}$ were also reported for their role in water splitting reactions [9-13]. In a previous research era, stupendous research has been done in the fabrication of active electrode material for oxygen evolution reactions (OERs). The main limitation with this method is that the OER at the anode gives rise to a high energy loss. Therefore, the emphasis has been given on attaining a high oxygen evolution rate at a low overpotential by optimizing the overall water splitting reaction. Electrode corrosion and low current densities are also the major disadvantages of conventional anode materials for OER [14]. Currently, ruthenium oxide has been used in the fabrication of dimensionally stable anodes (DSA), which havebeen employed to yield chlorine [15]. In addition, it has been used as a heterogeneous catalyst for the low temperature dehydrogenation of $\mathrm{NH}_{3}$ [16], $\mathrm{HCl}$ [17], and methanol [18], respectively. Further, ruthenium oxide was reported to work as anexcellent electrode material for OERs $[19,20]$ and hydrogen evolution reactions (HERs) [21,22]. The metallic conductivity of $\mathrm{RuO}_{2}$, along with $\mathrm{IrO}_{2}$,is of the order of $10^{4} \mathrm{ohm}^{-1} \mathrm{~cm}^{-1}$ [23]. $\mathrm{IrO}_{2}$ shows high corrosion-resistance, whereas $\mathrm{RuO}_{2}$ shows better OER activity [24]. Among all the other transition metal oxides, $\mathrm{RuO}_{2}$ and $\mathrm{IrO}_{2}$ are considered as the best electrocatalytic materials for electrolysis of water in acidic as well as an alkaline mediums $[25,26]$.

In the past few years, nanocrystalline $\mathrm{RuO}_{2}$ particles were synthesized by thermal evaporation [27], nanocasting [28], cryogenic decomposition of $\mathrm{RuO}_{4}$ [29] and electro-spinning [30]. Recently, M. P. Browne et al. [31] synthesized a series of $\mathrm{Mn}_{\mathrm{x}} \mathrm{O}_{\mathrm{y}} / \mathrm{RuO}_{2} / \mathrm{Ti}$ mixed oxide anode materials via a thermal decomposition method for OERs in alkaline medium. They have shown that electrocatalysts were containing different concentrations of Mn viz. $10 \%, 25 \%$ and $90 \%$ show almost similar or improved OER activity as compared to pure $\mathrm{RuO}_{2}$. Gustafson et al. [32] have synthesized $\mathrm{RuO}_{2}$ nanocatalyst for chemical and photochemical oxidation of water, which showed better catalytic performance as reported in the literature.

Presently, the artificial enzymes, i.e., nanoenzymes, are receiving significant attention of researchers due to their low cost, high catalytic property and thermal stability as compared to the natural enzymes. Prototypically, Gao et al. discovered that magnetite nanoparticles exhibit intrinsic peroxidase-like activity similar to that of a natural peroxidase enzyme [33]. $\mathrm{H}_{2} \mathrm{O}_{2}$ plays a vital role as an intermediate in food, pharmaceutical, clinical, and environmental analysis [34-36]. So, the detection of $\mathrm{H}_{2} \mathrm{O}_{2}$ has been done by using different nanoparticles. Besides that, $\mathrm{H}_{2} \mathrm{O}_{2}$ possesses a strong oxidizing property which may lead to different types of disorders in the body [37-39]. Hence, the detection of hydrogen peroxide is of a great practical feature.

Herein, we report the redox reaction of water (OER/ORR) happening through as-synthesized ruthenium oxide nanoparticles in $0.5 \mathrm{M} \mathrm{KOH}$ electrolytic solution at room temperature under different atmospheres (air, $\mathrm{N}_{2}$ and $\mathrm{O}_{2}$ ). Further, the as-synthesized ruthenium oxide nanoparticles were also used as a sensor for the detection of $\mathrm{H}_{2} \mathrm{O}_{2}$ in solution. Moreover, the synthesis of $\mathrm{RuO}_{2}$ nanoparticles was carried out through a simple, environmentally friendly and cost-effective wet chemical method at $80^{\circ} \mathrm{C}$ followed by annealing at $300^{\circ} \mathrm{C}$ for $6 \mathrm{~h}$.

\section{Results and Discussion}

The powder X-ray diffractometry was used for the structural analysis of the as-synthesized nanoparticles. Figure $1 \mathrm{a}$ shows the $\mathrm{X}$-ray diffraction pattern of the nanocrystalline $\mathrm{RuO}_{2}$. The obtained diffraction peaks are as follows at Bragg's angles of $27.8^{\circ}, 34.9^{\circ}, 39.8^{\circ}, 54.0^{\circ}, 57.6^{\circ}, 59.2^{\circ}, 65.2^{\circ}, 66.7^{\circ}$, $69.2^{\circ}, 73.8^{\circ}, 82.9^{\circ}$ and $87.3^{\circ}$ corresponds to the planes (110), (101), (200), (211), (220), (002), (310), (112), (301), (202), (321) and (222), respectively, which were correlated to a tetragonal unit cell of ruthenium oxide. The reflection pattern could be indexed to a pure tetragonal phase of $\mathrm{RuO}_{2}$ (JCPDS No. 065-2824). 
No peaks from any impurity or other phase or metallic Ru were detected, which affirms the formation of monophasic $\mathrm{RuO}_{2}$ nanoparticles.

The microstructure and surface texture of as-synthesized ruthenium oxide nanoparticles wereinvestigated through SEM studies. Figure $1 \mathrm{~b}$ shows the SEM micrograph of the as-synthesized nanoparticles. Further analysis of the SEM micrograph depicted the highlydense and agglomerated $\mathrm{RuO}_{2}$ nanoparticles. The nanoparticles aggregate randomly to form almost spherical shape with an average diameter of $28 \mathrm{~nm}$, which is as per the TEM analysis.
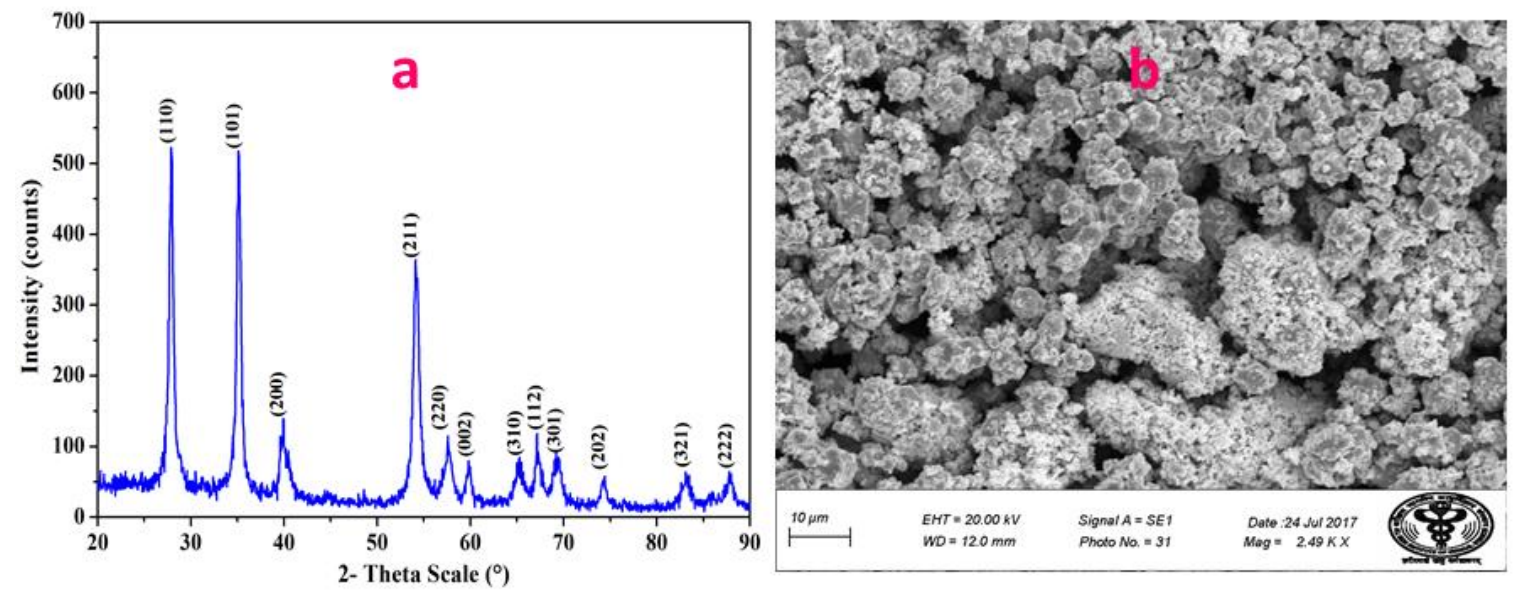

Figure 1. (a) X-ray diffraction pattern and (b) scanning electron microscope (SEM) micrograph of Ruthenium oxide nanoparticles.

The detailed structural analysis, shape and size distribution of $\mathrm{RuO}_{2}$ nanoparticles was done with the help of TEM studies. The low magnification TEM micrograph is shown in Figure 2a, which indicates the formation of tiny sized tetragonal $\mathrm{RuO}_{2}$ nanoparticles with slight agglomeration. Figure 2a also reveals that the small-sized nanoparticles tend to form large tetragonal structures, which are in accordance with X-ray diffraction studies. Furthermore, High Resolution Transmission Electron Microscope (HRTEM) analysis revealed the crystal structure, phase and growth direction of as-synthesized nanoparticles. Figure $2 b$ shows the typical HRTEM image of ruthenium oxide nanoparticles, which depicts the well-resolved lattice fringes with an average lattice distance of $3.210 \pm 0.05 \AA$ and $2.560 \pm 0.05 \AA$ corresponding to (110) and (101) planes, respectively, of ruthenium oxide nanoparticles. The TEM average size distribution histogram of ruthenium oxide nanoparticles are shown in Figure 2c, which indicates that the particle size ranges from $5 \mathrm{~nm}$ to $35 \mathrm{~nm}$, as the various small particles have combined to form a single massive particle. The average grain size was found to be $\sim 20 \mathrm{~nm}$ by using TEM micrograph as well as a size distribution plot. 

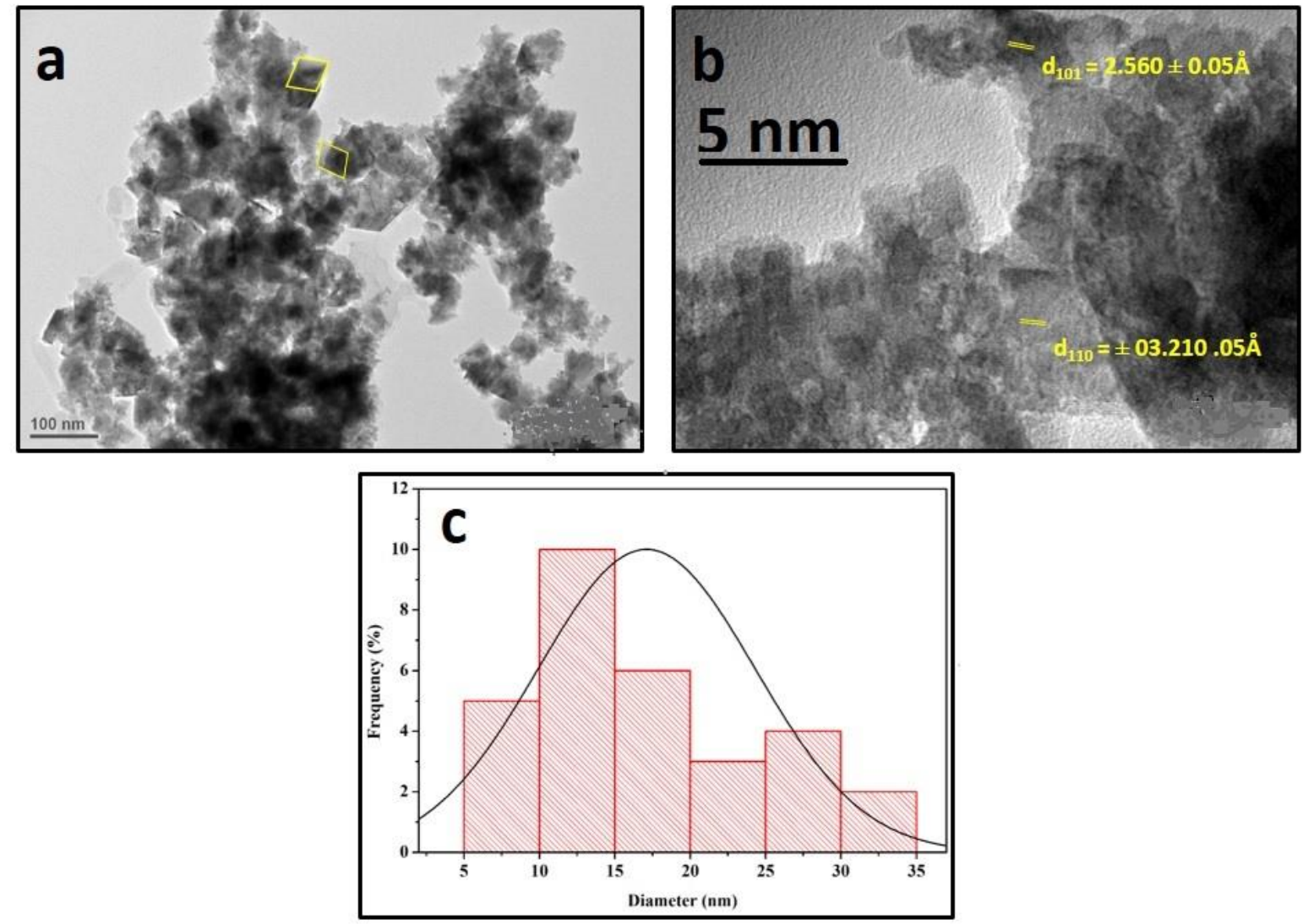

Figure 2. (a) TEM micrograph, (b) HR-TEM image and (c) size distribution histogram of Ruthenium oxide nanoparticles.

The specific surface area of as-prepared $\mathrm{RuO}_{2}$ nanoparticles was estimated by using a multipoint BET equation that showed the linear relationship in the $\mathrm{P} / \mathrm{P}_{0}$ range of $0.05-0.35$. Figure 3 a shows the BET plot for $\mathrm{RuO}_{2}$ nanoparticles. The specific surface area was found to be $64.5 \mathrm{~m}^{2} \mathrm{~g}^{-1}$, which agrees with the earlier reported value [19]. The BJH (Barrett-Joyner-Halenda) model was used to determine the pore size. The pore size distribution plot of ruthenium oxide nanoparticles (Figure $3 \mathrm{~b}$ ) gives the pore radius value of $16 \AA$, which lies in the range of mesoporous materials. The pore radius was also determined by the DA (Dubinin-Astakhov) plot, as shown in Figure 3c, and it was found to be $13.5 \AA$, which is a bit smaller than the $\mathrm{BJH}$ results. 

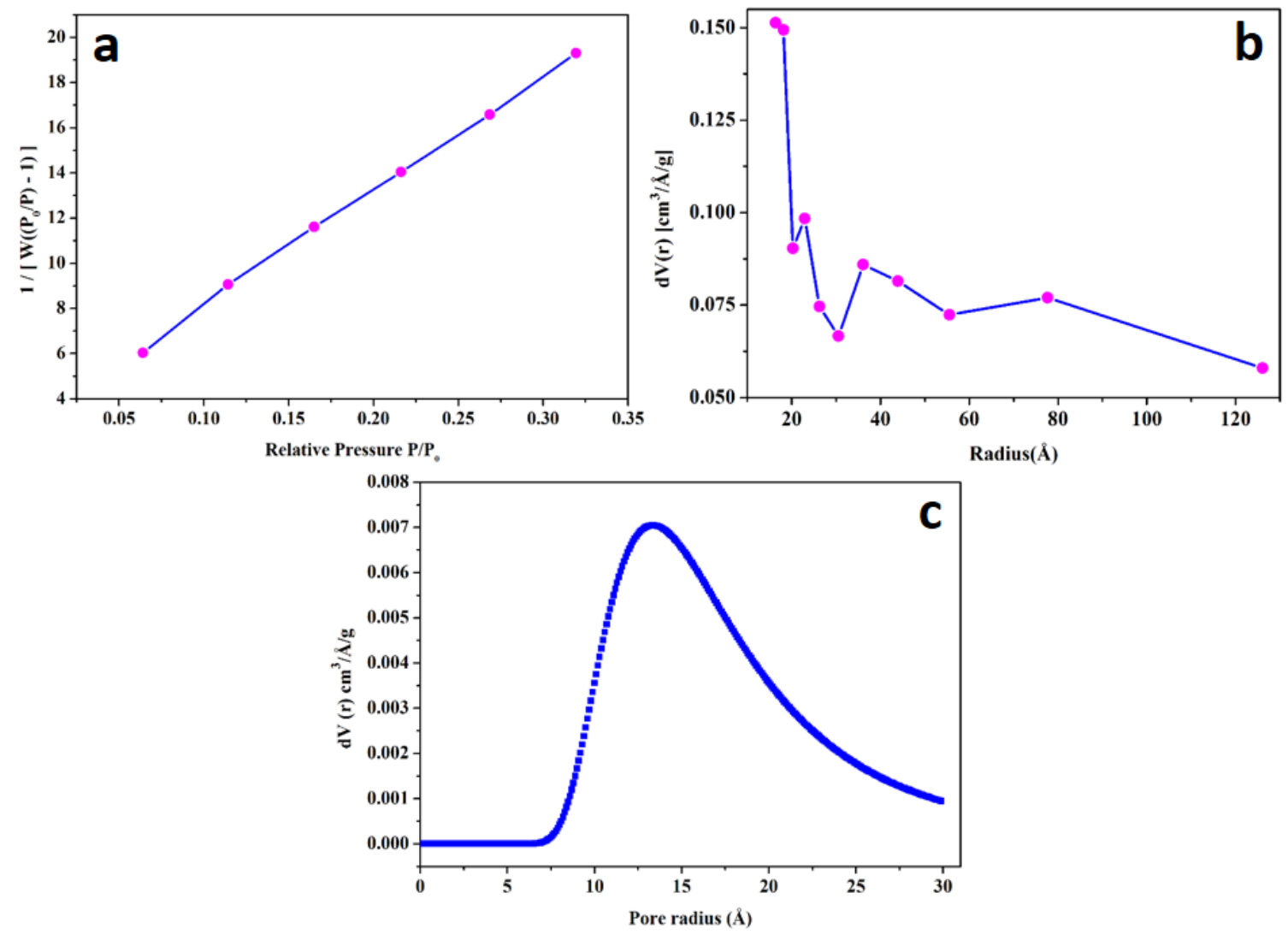

Figure 3. (a) BET, (b) BJH and (c) DA pore radius plots of ruthenium oxide nanoparticles.

The electrocatalytic activity of as-prepared nanoparticles for oxygen evolution reaction (OER) and oxygen reduction reaction (ORR) was evaluated by cyclic voltammetry (CV), linear sweep voltammetry (LSV) and Tafel polarization curves in $0.5 \mathrm{M} \mathrm{KOH}$ electrolyte solution. The CV plots for OER (anodic sweep) and ORR (cathodic sweep) by ruthenium oxide electrode at the scan rate of $25 \mathrm{mVs}^{-1}$ in the air (black), $\mathrm{N}_{2}$ (red) and saturated $\mathrm{O}_{2}$ (blue) atmosphere are shown in Figure 4a. The CV curves show that the OER starts from the low potential value of $\sim 1.5 \mathrm{~V}$ vs. RHE (reversible hydrogen electrode). Figure 4 a shows that the as-synthesized $\mathrm{RuO}_{2}$ nanoparticles generate more current in $\mathrm{O}_{2}$ saturated $\left(17.5 \mathrm{mAcm}^{-2}\right)$ as compared to air $\left(11.5 \mathrm{mAcm}^{-2}\right)$ and $\mathrm{N}_{2}\left(10.5 \mathrm{mAcm}^{-2}\right)$ atmosphere at $1.55 \mathrm{~V}$ vs. RHE at $25 \mathrm{mVs}^{-1}$ for the oxygen evolution reaction. The ORR activity of ruthenium oxide nanoparticles in alkaline medium is also shown in Figure 4a. It was observed that as-synthesized $\mathrm{RuO}_{2}$ nanoparticles show an almost comparable ORR reaction in all the atmospheric conditions. The LSV measurements optimized the electrocatalytic activity of ruthenium oxide nanoparticles in $0.5 \mathrm{M} \mathrm{KOH}$ electrolyte at the scan rate of $25 \mathrm{mVs}^{-1}$. Figure $4 \mathrm{~b}$ shows the LSV curves under air, nitrogen and $\mathrm{O}_{2}$ saturated atmospheres. It was observed that the onset potential for OER was found to be $\sim 1.5\left(\mathrm{O}_{2}\right)$ and $\sim 1.61 \mathrm{~V}$ (air and $\mathrm{N}_{2}$ ) vs. RHE. Notably, the resulting current density (current/area of the electrode) of $\mathrm{RuO}_{2}$ electrode is directly related to the amount of oxygen evolved from the electrolysis of water. The geometric electro-active surface area of the working electrode could be estimated from the Randles-Sevik equation [40]. The current density of $\mathrm{RuO}_{2}$ electrode at $\sim 1.7 \mathrm{~V}$ versus RHE at $25 \mathrm{mVs}^{-1}$ was found to be $\sim 9.6 \mathrm{mAcm}^{-2}$ (in $\mathrm{N}_{2}$ ), $\sim 11.9 \mathrm{mAcm}^{-2}$ (in air) and $\sim 15.5 \mathrm{mAcm}^{-2}$ (in $\mathrm{O}_{2}$ ). The significance of LSV measurements is to find the onset potential, reaction kinetics and mechanism of the reaction, i.e., to identify the number of electrons taking part in the electrochemical reaction. Figure $4 \mathrm{c}$ shows the LSV curves of $\mathrm{RuO}_{2}$ nanoparticles for the oxygen reduction reaction in air, $\mathrm{N}_{2}$, and $\mathrm{O}_{2}$ saturated $0.5 \mathrm{M} \mathrm{KOH}$ at the scan rate of $25 \mathrm{mVs}^{-1}$. From this study, we clearly observed that the ORR activity performed significantly better in an $\mathrm{O}_{2}$-saturated system compared to other systems 
as expected. The ORR activity in air could be due to the dissolved oxygen in system. Note that very weak ORR activity in $\mathrm{N}_{2}$ was also observed, which could be due to the presence of oxygen content $(5 \%)$ in $\mathrm{N}_{2}$. The onset potential for ORR was found to be $0.7 \mathrm{~V}$ vs. RHE. Choronoamperometric (CA) measurements demonstrated the stability and the electrocatalyticactivity of the ruthenium oxide electrode at a fixed potential ( $1.5 \mathrm{~V}$ vs. RHE) in $\mathrm{O}_{2}$-saturated $0.5 \mathrm{M} \mathrm{KOH}$ for $200 \mathrm{~s}$. Figure $4 \mathrm{~d}$ shows the CA curves, which demonstrate that the material is stable, and the constant current is generated with time. It was observed that the resulting current densities were consistent with time. The CA experiments also showed that on turning off the potential, the water redox reaction was stopped instantly, and therefore the current density dropped to zero. The current density obtained was directly proportional to the amount of gas evolved during the OER. The surface area of the electrode material used, and the Faradaic and Non-Faradaic processes were responsible for the resulting current density.
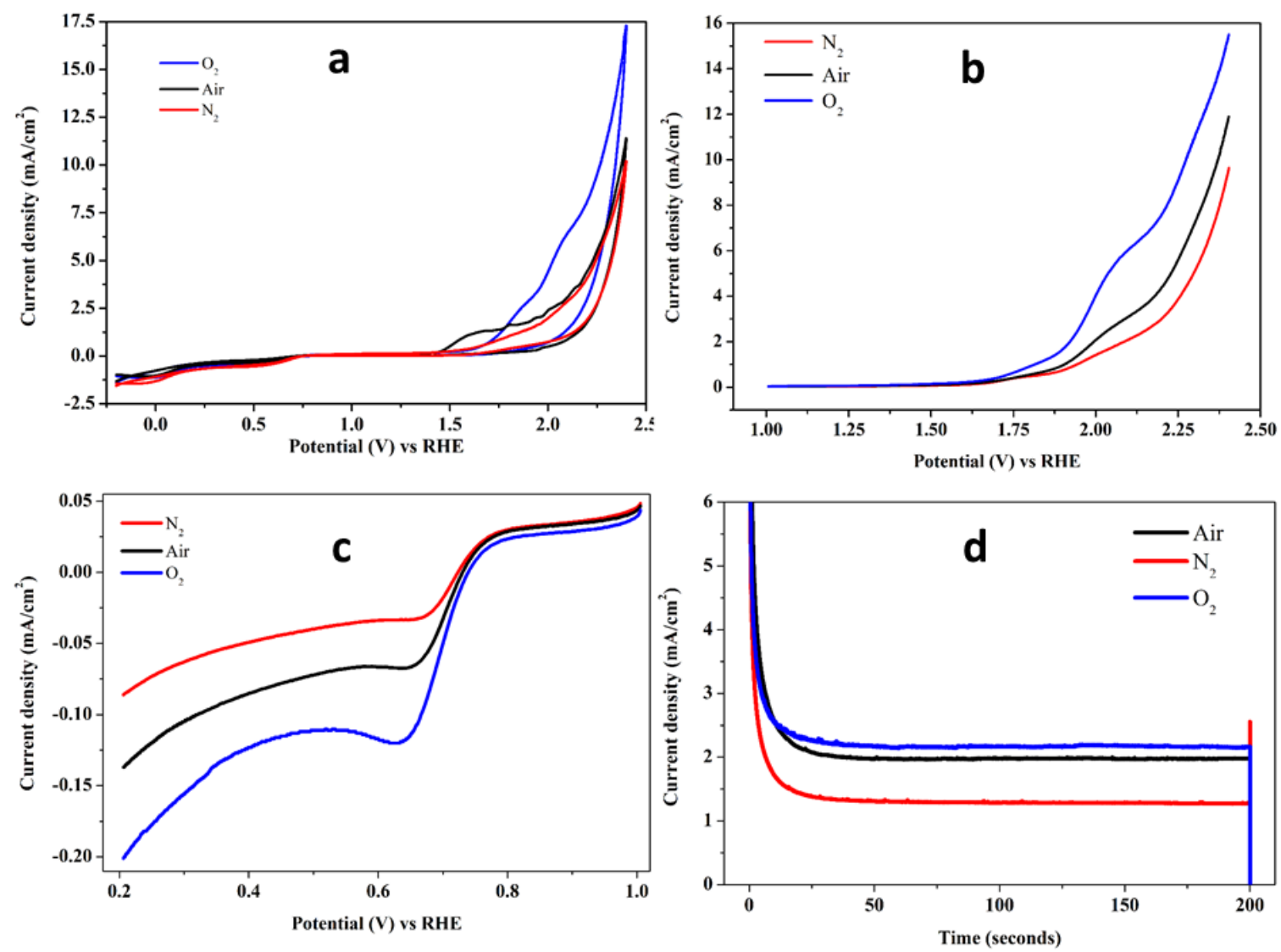

Figure 4. (a) CV, (b) LSV (OER), (c) LSV (ORR) curves of Ruthenium oxide photoanode in air, $\mathrm{N}_{2}$ and $\mathrm{O}_{2}$ saturated $0.5 \mathrm{M} \mathrm{KOH}$ electrolyte vs. RHE at the scan rate of $25 \mathrm{mVs}^{-1}$ and (d) CA curves of Ruthenium oxide nanoparticles for OER activity at $1.5 \mathrm{~V}$ vs. RHE in $\mathrm{O}_{2}$-saturated $0.5 \mathrm{M} \mathrm{KOH}$.

The Tafel polarization studies determined the kinetics of the reaction, i.e., electrolysis of water. It was observed that reaction kinetics strongly depends upon the size, surface area, morphology and orientation of electrocatalysts $[14,41]$. Figure $5 \mathrm{a}, \mathrm{b}$ shows the Tafel polarization plot of ruthenium oxide nanoparticles for the water redox reactions (OER and ORR) in air, and $\mathrm{O}_{2}$, respectively. The linear curve fitting calculated the value of Tafel slopes of ruthenium oxide nanoparticles, and it comes out to be 76 , and $47 \mathrm{mVdec}^{-1}$ in air, and $\mathrm{O}_{2}$, respectively, for OER while for ORR, these values were found to be 48 (air), and $49 \mathrm{mVdec}^{-1}\left(\mathrm{O}_{2}\right)$ with the experimental error of \pm 5 . The effective electro-active catalysts for water splitting could lower the Tafel slope values to sustain the high activity, stability and to enhance the efficiency by reducing the loss of energy during the electrochemical reactions [42]. 
The comparison in the current electrocatalytic activities viz. OER/ORR of $\mathrm{RuO}_{2}$ nanoparticles with the literature has been tabulated in Table 1 .
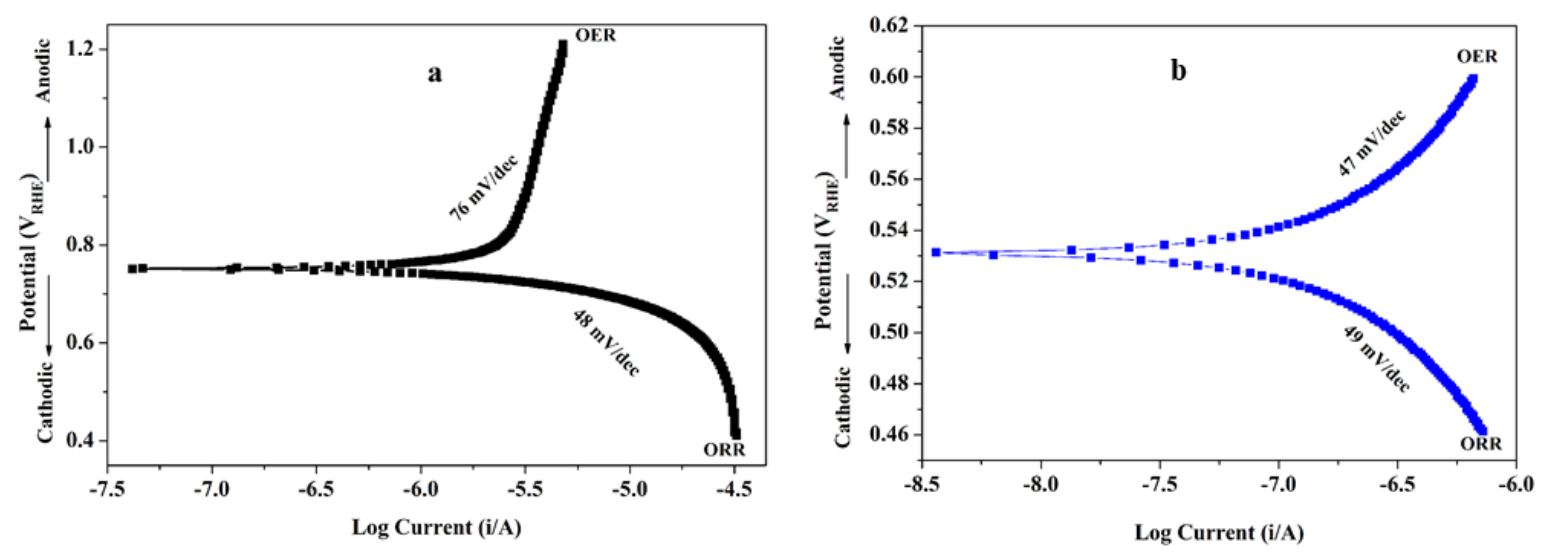

Figure 5. Tafel polarization curves of Ruthenium oxide nanoparticles for OER and ORR in (a) air, and (b) $\mathrm{O}_{2}$ saturated atmosphere at $10 \mathrm{mVs}^{-1}$.

Table 1. Comparison of OER/ORR activity of $\mathrm{RuO}_{2}$ nanoparticles with other reported literature.

\begin{tabular}{|c|c|c|c|c|c|c|}
\hline \multirow[t]{2}{*}{ Catalyst } & \multirow[t]{2}{*}{ Electrolyte } & \multirow{2}{*}{$\begin{array}{c}\text { Scan Rate } \\
\left(\mathrm{mVs}^{-1}\right)\end{array}$} & \multirow{2}{*}{$\begin{array}{c}\text { Onset Potential } \\
\text { (V/RHE) }\end{array}$} & \multicolumn{2}{|c|}{$\begin{array}{l}\text { TafelSlope } \\
\left.\text { (mVdec }^{-1}\right)\end{array}$} & \multirow[t]{2}{*}{ Ref. } \\
\hline & & & & OER & ORR & \\
\hline $\mathrm{r}-\mathrm{RuO}_{2}$ & $0.1 \mathrm{M} \mathrm{KOH}$ & 10 & 1.4 & - & - & [25] \\
\hline $\mathrm{Ru} @ \mathrm{RuO}_{2}$ & $0.1 \mathrm{M} \mathrm{KOH}$ & 10 & 1.3 & 86 & - & [43] \\
\hline $1 \mathrm{D}-\mathrm{RuO}_{2}-\mathrm{CN}_{\mathrm{x}}$ & $0.5 \mathrm{M} \mathrm{KOH}$ & 10 & 1.42 & 56 & - & [44] \\
\hline $\mathrm{RuO}_{2}$ & $0.05 \mathrm{M} \mathrm{NaOH}$ & 10 & 1.27 & - & - & [45] \\
\hline $\mathrm{Mn}_{25} \mathrm{Ru}_{75} @ 450$ & $1 \mathrm{M} \mathrm{NaOH}$ & 10 & 1.4 & 66 & - & [31] \\
\hline $\mathrm{RuO}_{2}$ nanoparticles & $0.5 \mathrm{M} \mathrm{KOH}$ & 25 & 1.5 & 47 & 49 & Present work \\
\hline
\end{tabular}

The catalytic activity of as-synthesized nanoparticles depends on the concentration of $\mathrm{H}_{2} \mathrm{O}_{2}$, and the reaction temperature just like that of HRP [33]. The catalytic oxidation of TMB substrate by $\mathrm{RuO}_{2}$ nanoparticles at a range of $\mathrm{H}_{2} \mathrm{O}_{2}$ concentration and temperature is shown in Figure 6. It was observed that to attain maximum activity; the $\mathrm{RuO}_{2}$ nanoparticles required a very high concentration of $\mathrm{H}_{2} \mathrm{O}_{2}$ (1M) as compared to HRP and on further increasing the concentration of $\mathrm{H}_{2} \mathrm{O}_{2}$ the catalytic activity was suppressed (Figure 6a). The effect of temperature on the catalytic activity of the $\mathrm{RuO}_{2}$ nanoparticles was checked in the temperature range of $20-90^{\circ} \mathrm{C}$. Figure $6 \mathrm{~b}$ indicates that the catalytic activity of $\mathrm{RuO}_{2}$ nanoparticles increases with the increase in temperature till $60^{\circ} \mathrm{C}$ and with further increase in temperature up to $90{ }^{\circ} \mathrm{C}$ the activity was quenched. Whereas, HRP shows maximum activity at $30{ }^{\circ} \mathrm{C}$ and it shows no activity at higher temperature, i.e., above $60^{\circ} \mathrm{C}$. The as-synthesized nanoparticles showed better activity at a wide range of temperature compared to HRP catalyst. The thermal stability of the $\mathrm{RuO}_{2}$ nanoparticles and HRP was determined by incubating the reaction mixture with TMB substrate at $80{ }^{\circ} \mathrm{C}$ for $90 \mathrm{~min}$, and the aliquots were taken at regular time intervals. It was found that the catalytic activity of $\mathrm{RuO}_{2}$ nanoparticles was almost preserved until 90 min at $80{ }^{\circ} \mathrm{C}$ while the HRP showed no activity in similar reaction conditions (Figure $6 \mathrm{c}$ ). We have also analyzed the sensitivity of $\mathrm{RuO}_{2}$ nanoparticles for the detection of $\mathrm{H}_{2} \mathrm{O}_{2}$ in solution. The aliquots containing different concentration of $\mathrm{H}_{2} \mathrm{O}_{2}$ and colourimetric reagent were taken and analyzed via spectrophotometry. Figure $6 \mathrm{~d}$ shows the absorbance at $505 \mathrm{~nm}$, which increases nearly linearly as the concentration of $\mathrm{H}_{2} \mathrm{O}_{2}$ increased. 

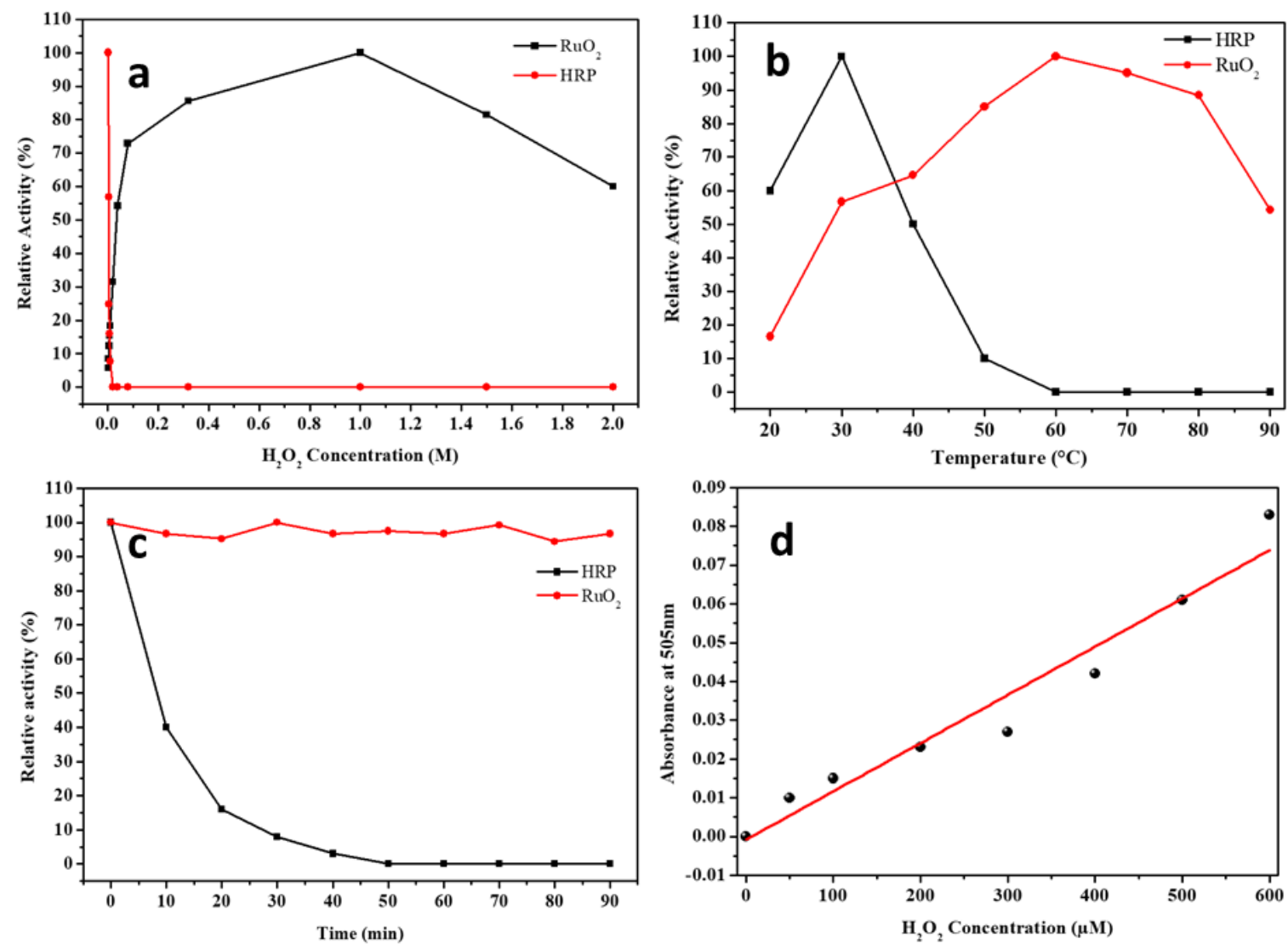

Figure 6. (a) $\mathrm{H}_{2} \mathrm{O}_{2}$ concentration optima and (b) temperature optima plots, (c) thermal stability (at $80^{\circ} \mathrm{C}$ for $90 \mathrm{~min}$ under the standard reaction conditions) and (d) sensitivity (at $505 \mathrm{~nm}$ for the different concentrations of $\mathrm{H}_{2} \mathrm{O}_{2}$ ) of ruthenium oxide nanoparticles.

\section{Experimental}

Ruthenium (III) chloride ( $\mathrm{RuCl}_{3} \cdot \mathrm{xH}_{2} \mathrm{O}$, Alfa Aesar, Haverhill, MA, USA, 99.9\%), $\mathrm{NaOH}(\mathrm{Merck}$ India Ltd., Mumbai, India), hydrogen peroxide ( $50 \% w / v$, Merck India Ltd.), HRP and Tetramethylbenzidine (SRL, Mumbai, India) were used without further purification. $1.3 \mathrm{mmol}$ of $\mathrm{RuCl}_{3} \cdot \mathrm{xH}_{2} \mathrm{O}$ was dissolved in $50 \mathrm{~mL}$ of water in a two-neck flask, followed by the dropwise addition of $1.5 \mathrm{M}$ aqueous $\mathrm{NaOH}$ to a $\mathrm{pH} \sim 8$. The solution was continuously stirred and refluxed at $80^{\circ} \mathrm{C}$ untilthe black precipitate was observed. The black precipitate was collected through centrifugation process and repeatedly washed with double-distilled water followed by ethanol to remove the $\mathrm{Cl}^{-}$ions. The $\mathrm{Cl}^{-}$ions present in the supernatant liquid were checked with the aqueous solution of silver nitrate. The black precipitate was dried at $100{ }^{\circ} \mathrm{C}$ in the hot-air oven and grounded to form a fine powder. Further, the black colour powder was annealed at $300{ }^{\circ} \mathrm{C}$ for $6 \mathrm{~h}$ in a high temperature furnace to obtained black colour ruthenium oxide nanoparticles. The as-synthesized nanoparticles were further employed to study the catalytic activity.

\subsection{Physical Characterization}

Powder X-ray diffraction (XRD) was performed using a RigakuUltima IV X-ray diffractometer with Ni-filtered $\mathrm{Cu}-\mathrm{K} \alpha$ radiation $(\lambda=1.5416 \AA)$. The morphological features of synthesized ruthenium oxide nanoparticles were determined by Zeiss EVO40 Scanning Electron Microscope (SEM) at an accelerating voltage of $20 \mathrm{kV}$. Transmission electron microscopic (TEM) analysis was carried out on FEI Technai $G^{2} 20$ HRTEM (High Resolution Transmission Electron Microscope) with an accelerating voltage of $200 \mathrm{kV}$. The surface area and the pore size of as-synthesized nanoparticles were determined using 
Brunauer-Emmett-Teller (BET) surface area analyzer (Model: Nova 2000e, Quantachrome Instruments Limited, Boynton Beach, FL, USA) at liquid nitrogen temperature (77K).

\subsection{Electrochemical Measurements}

The electrolysis of water for OER and ORR was carried out with a three-electrode electrochemical work station (potentiostat/galvanostat, $\mathrm{CHI} 660 \mathrm{E}$, Shenzhen, China) at room temperature in alkaline medium $(0.5 \mathrm{M} \mathrm{KOH})$ to investigate the redox behaviour of the synthesized $\mathrm{RuO}_{2}$ nanoparticles. $\mathrm{Pt}$ wire, $\mathrm{Ag} / \mathrm{AgCl}$ and glassy carbon electrodes were used as the counter, reference, and working electrodes in the electrochemical analyzer. The reference electrode $(\mathrm{Ag} / \mathrm{AgCl})$ was converted to the reversible hydrogen electrode (RHE) as per the conversion equation, i.e., Nernst Equation at $25{ }^{\circ} \mathrm{C}$.

$$
\mathrm{E}_{\mathrm{RHE}}=\mathrm{E}_{\mathrm{Ag} / \mathrm{AgCl}}+0.059 \mathrm{pH}+0.197 \mathrm{~V}
$$

The slurry was prepared by sonicating $2.5 \mathrm{mg}$ of catalysts in $0.5 \mathrm{~mL}$ of isopropanol with $0.1 \mathrm{~mL}$ of Nafion solution for $10 \mathrm{~min}$. Then a drop of the slurry was cast on the surface of glassy carbon and dried at $60{ }^{\circ} \mathrm{C}$ in vacuum oven $[46,47]$. The loaded amount of the nanoparticles was of $\sim 0.30 \mathrm{mg} / \mathrm{cm}^{2}$ on the GC electrode, and the area of the working electrode was $0.07 \mathrm{~cm}^{2}$. Freshly prepared electrodes were used for the electrochemical measurements. Cyclic Voltammetry (CV), linear sweep voltammetry (LSV) and Tafel measurements were done by applying redox potential versus $\mathrm{Ag} / \mathrm{AgCl}$ electrode for OER and ORR at the scan rate of $25 \mathrm{mV} \mathrm{s}^{-1}$ in $0.5 \mathrm{M} \mathrm{KOH}$ electrolyte at room temperature in air, nitrogen and saturated oxygen atmosphere.

\subsection{Catalytic Activity of $\mathrm{RuO}_{2}$ Nanoparticles and $\mathrm{HRP}$}

The catalytic activity of as-synthesized nanoparticles and HRP was checked by peroxidase substrate Tetramethylbenzidine (TMB) [48]. In a typical procedure, $200 \mu \mathrm{L}$ of $\mathrm{RuO}_{2}$ nanoparticles ( $2 \mathrm{mg} / \mathrm{mL}), 1.5 \mathrm{~mL} \mathrm{TMB}$, and $5 \mu \mathrm{L} \mathrm{H}_{2} \mathrm{O}_{2}$ were added in $1 \mathrm{~mL}$ of $0.02 \mathrm{M}$ acetate buffer $(\mathrm{Ph} \sim 4.5)$ and incubated in a water-bath at $30^{\circ} \mathrm{C}$ for $10 \mathrm{~min}$ and the progress of the reaction was monitored by $\mathrm{A}$ Shimadzu UV-2450 spectrophotometer. The leaching of the ions from the reaction mixture was checked by incubating a suspension of $\mathrm{RuO}_{2}$ nanoparticles in acetate buffer $(5 \mathrm{mg} / \mathrm{mL}, \mathrm{Ph} 3.5)$ (marked as control) for $10 \mathrm{~min}$ at $45^{\circ} \mathrm{C}$; the nanoparticles were removed from the reaction mixture, and the catalytic activity of the reaction mixture was analyzed. No activity was found in control. In order to investigate the effect of $\mathrm{H}_{2} \mathrm{O}_{2}$ concentration on the activity of as-synthesized nanoparticles, it was examined by varying the concentrations of $\mathrm{H}_{2} \mathrm{O}_{2}(0.002-2 \mathrm{M})$. The effect of change of temperature on the activity of $\mathrm{RuO}_{2}$ nanoparticles was determined by incubating the reaction mixture from 20 to $90^{\circ} \mathrm{C}$. The obtained results were compared with the activity of HRP enzyme over the same range of parameters.

\subsection{Detection of $\mathrm{H}_{2} \mathrm{O}_{2}$}

In a typical experiment, $1 \mathrm{~mL}$ hydrogen peroxide $(50-600 \mu \mathrm{M})$ was added to the $1 \mathrm{mLcolourimetric}$ reagent, i.e., $10 \mathrm{mg}$ phenol, $10 \mathrm{mg}$ of 4 -aminoantipyrine, $50 \mathrm{mg}$ of $\mathrm{RuO}_{2}$ nanoparticles, dissolved in $20 \mathrm{~mL}$ of $100 \mathrm{mM}$ acetic acid buffer ( $\mathrm{pH}$ 5.6) [49]. The test tubes containing different concentrations of $\mathrm{H}_{2} \mathrm{O}_{2}$ and blank, i.e., without $\mathrm{H}_{2} \mathrm{O}_{2}$ were incubated in a water-bath for $10 \mathrm{~min}$ at $30{ }^{\circ} \mathrm{C}$, and the progress of the reaction was monitored by spectrophotometer at $505 \mathrm{~nm}$.

\section{Conclusions}

We have successfully synthesized the ultrafine ruthenium oxide nanoparticles via a simple co-precipitation method at $300{ }^{\circ} \mathrm{C}$. The application of synthesized nanoparticles was successfully studied, and it was concluded that $\mathrm{RuO}_{2}$ nanoparticles are an effective bifunctional and stable material for OER and ORR reactions in the air, $\mathrm{N}_{2}$ and $\mathrm{O}_{2}$ atmosphere. Also, $\mathrm{RuO}_{2}$ nanoparticles were used as sensors for the detection of $\mathrm{H}_{2} \mathrm{O}_{2}$ in a solution. The $\mathrm{RuO}_{2}$ nanoparticles have a comparable limit of detection and linear dynamic values ranging from 600 to $10 \mu \mathrm{M}$ of $\mathrm{H}_{2} \mathrm{O}_{2}$. The economically viable 
as-synthesized nanoparticles could be used as an active nonenzymatic electrochemical sensor for the selective detection of $\mathrm{H}_{2} \mathrm{O}_{2}$. Further, these nanoparticles showed efficient electrocatalytic activity with low energy loss. Tafel slopes were found to be very low and the electrode material was stable as established by CA studies. Therefore, the ruthenium oxide nanoparticles consumed less energy during the water redox reaction (OER and ORR) and proved to be a better electrode material for OER/ORR reactions, showing its excellent potential for further applications in the future.

Author Contributions: R.P. is responsible for the experimental reactions, basic characterization and first draft of the manuscript, M.P. did the detection of $\mathrm{H}_{2} \mathrm{O}_{2}$ measurements, J.A. did the electrochemical measurement and its discussion, M.S. was the co-supervisor of first author and wrote the discussion part for the detection of $\mathrm{H}_{2} \mathrm{O}_{2}$ measurements, S.M.A. helps in the editing and electrochemical measurements, N.A. designed the electrochemical set for the water redox reaction and did the primary measurements, M.A.M.K.helps in the discussion and measurements electrochemical studies and T.A. is responsible for supervision, creation ideas, infrastructure, editing and final draft of the manuscript. All authors have read and agreed to the published version of the manuscript.

Funding: This research was funded by the scheme (SPARC/2018-2019/P843/SL) of MHRD, Government of India and King Saud University Research Project (RSP-2020/29).

Acknowledgments: T.A. thanks the MHRD-SPARC scheme of the Government of India for financial support. R.P. especially thanks to UGC, New Delhi, for the Senior Research Fellowship. Authors also acknowledge the measurement support provided through the DST PURSE program at CIF, Jamia Millia Islamia and AIIMS, New Delhi for electron microscopic studies. The authors extend their sincere appreciation to the Researchers Supporting Project at King Saud University for funding this Research.

Conflicts of Interest: The authors declare that there is no conflict of interest.

\section{References}

1. Solomonn, S.; Plattner, G.-K.; Knutti, R.; Friedlingstein, P. Irreversible climate change due to carbon dioxide emissions. Proc. Natl. Acad. Sci. USA 2009, 106, 1704-1709. [CrossRef] [PubMed]

2. Chhow, J.; Kopp, R.J.; Portney, P.R. Energy resources and global development. Science 2003, 302, $1528-1531$. [CrossRef] [PubMed]

3. Ahmad, T.; Lone, I.H.; Ansari, S.G.; Ahmed, J.; Ahamad, T.; Alshehri, S.M. Multifunctional properties and applications of yttrium ferrite nanoparticles prepared by citrate precursor route. Mater. Des. 2017, 126, 331-338. [CrossRef]

4. Vondrák, J.; Klápště, B.; Velická, J.; Sedlaříková, M.; Ćerný, R. Hydrogen-oxygen fuel cells. J. Solid State Electrochem. 2003, 8, 44-47. [CrossRef]

5. Zhang, X.; Wang, X.-G.; Xie, Z.; Zhou, Z. Recent progress in rechargeable alkali metal-air batteries. Green Energy Environ. 2016, 1, 4-17. [CrossRef]

6. Gutsche, C.; Moeller, C.J.; Knipper, M.; Borchert, H.; Parisi, J.; Plaggenborg, T. Synthesis, structure, and electrochemical stability of Ir-decorated $\mathrm{RuO}_{2}$ nanoparticles and Ptnanorods as oxygen catalysts. J. Phys. Chem. C. 2016, 120, 1137-1146. [CrossRef]

7. Tseng, H.-W.; Zong, R.; Muckerman, J.T.; Thummel, R. Mononuclear ruthenium (II) complexes that catalyze water oxidation. Inorg. Chem. 2008, 47, 11763-11773. [CrossRef]

8. Reier, T.; Oezaslan, M.; Strasser, P. Electrocatalytic oxygen evolution reaction (OER) on Ru, Ir, and Ptcatalysts: A comparative study of nanoparticles and bulk materials. ACS Catal. 2012, 2, 1765-1772. [CrossRef]

9. Karlsson, E.A.; Lee, B.-L.; Åkermark, T.; Johnston, E.V.; Kärkäs, M.D.; Sun, J.; Hansson, Ö.; Bäckvall, J.-E.; Åkermark, B. Photosensitized water oxidation by use of a bioinspired manganese catalyst. Angew. Chem. Int. Ed. 2011, 50, 11715-11718. [CrossRef]

10. Ellis, W.C.; McDaniel, N.D.; Bernhard, S.; Collins, T.J. Fast water oxidation using iron. J. Am. Chem. Soc. 2010, 132, 10990-10991. [CrossRef]

11. Alshehri, S.M.; Ahmed, J.; Alhabarah, A.N.; Ahamad, T.; Ahmad, T. Nitrogen doped cobalt ferrite/carbon nanocomposites for supercapacitor application. ChemElectroChem 2017, 4, 2952-2958. [CrossRef]

12. Coggins, M.; Zhang, K.M.T.; Chen, Z.; Song, N.; Meyer, T.J. Single-site copper (II) water oxidation electrocatalysis: Rate enhancements with $\mathrm{HPO}_{4}{ }^{2-}$ as a proton acceptor at $\mathrm{pH}-8$. Angew. Chem. Int. Ed. Engl. 2014, 53, 12226-12230. [CrossRef] [PubMed] 
13. Alshehri, S.M.; Ahmed, J.; Ahamad, T.; Alhokbany, N.; Arunachalam, P.; Al-Mayouf, A.M.; Ahmad, T. Synthesis, characterization, multifunctional electrochemical (OGR/ORR/SCs) and photodegradable activities of $\mathrm{ZnWO}_{4}$ nanobricks. J. Sol-Gel Sci. Technol. 2018, 87, 137-146. [CrossRef]

14. Fang, Y.-H.; Liu, Z.-P. Mechanism and tafel lines of electro-oxidation of water to oxygen on $\mathrm{RuO}_{2}$ (110). J. Am. Chem. Soc. 2010, 132, 18214-18222. [CrossRef]

15. Michas, A.; Andolfatto, F.; Lyons, M.E.G.; Durand, R. Gas evolution reactions at conductive metallic oxide electrodes for solid polymer electrolyte water electrolysis. Key Eng. Mater. 1992, 535, 72-74. [CrossRef]

16. Cui, X.; Zhou, J.; Ye, Z.; Chen, H.; Li, L.; Ruan, M.; Shi, J. Selective catalytic oxidation of ammonia to nitrogen over mesoporous $\mathrm{CuO} / \mathrm{RuO}_{2}$ synthesized by co-nanocasting-replication method. J. Catal. 2010, 270, 310-317. [CrossRef]

17. Seki, K. Development of $\mathrm{RuO}_{2} /$ Rutile- $-\mathrm{TiO}_{2}$ catalyst for industrial $\mathrm{HCl}$ oxidation process. Catal. Surv. Asia 2010, 14, 168-175. [CrossRef]

18. Liu, H.; Iglesia, E. Selective oxidation of methanol and ethanol on supported ruthenium oxide clusters at low temperatures. J. Phys. Chem. B 2005, 109, 2155-2163. [CrossRef]

19. Ma, H.; Liu, C.; Liao, J.; Su, Y.; Xue, X.; Xing, W. Study of ruthenium oxide catalyst for electrocatalytic performance in oxygen evolution. J. Mol. Catal. A-Chem. 2006, 247, 7-13. [CrossRef]

20. Kiele, N.M.; Herrero, C.; Ranjbari, A.; Aukauloo, A.; Grigoriev, S.A.; Villagra, A.; Millet, P. Ruthenium-based molecular compounds for oxygen evolution in acidic media. Int. J. Hydrogen Energy 2013, 38, 8590-8596. [CrossRef]

21. Jeon, H.S.; Permana, A.D.C.; Kim, J.; Min, B.K. Water splitting for hydrogen production using a high surface area $\mathrm{RuO}_{2}$ electrocatalyst synthesized in supercritical water. Int. J. Hydrogen Energy 2013, 38, 6092-6096. [CrossRef]

22. Tilley, S.D.; Schreier, M.; Azevedo, J.; Stefik, M.; Grätzel, M. Ruthenium oxide hydrogen evolution catalysis on composite cuprous oxide water-splitting photocathodes. Adv. Funct. Mater. 2014, 24, 303-311. [CrossRef]

23. Ryden, W.D.; Lawson, A.W.; Sartain, C.C. Temperature dependence of the resistivity of $\mathrm{RuO}_{2}$ and $\mathrm{IrO}_{2}$. Phys. Lett. 1968, 26, 209-210. [CrossRef]

24. Hu, J.-M.; Zhang, J.-Q.; Cao, C.-N. Oxygen evolution reaction on $\mathrm{IrO}_{2}$-based DSA®type electrodes: Kinetics analysis of tafel lines and EIS. Int. J. Hydrogen Energy 2004, 29, 791-797. [CrossRef]

25. Lee, Y.; Suntivich, J.; May, K.J.; Perry, E.E.; Shao-Horn, Y. Synthesis and activities of rutile $\mathrm{IrO}_{2}$ and $\mathrm{RuO}_{2}$ nanoparticles for oxygen evolution in acid and alkaline solutions. J. Phys. Chem. Lett. 2012, 3, $399-404$. [CrossRef]

26. Ahmed, J.; Mao, Y. Ultrafine iridium oxide nanorods synthesized by molten salt method toward electrocatalytic oxygen and hydrogen evolution reactions. Electrochim. Acta 2016, 212, 686-693. [CrossRef]

27. Chen, Y.M.; Korotcov, A.; Hsu, H.P.; Huang, Y.S.; Tsai, D.S. Raman scattering characterization of well-aligned $\mathrm{RuO}_{2}$ nanocrystals grown on sapphire substrates. New J. Phys. 2007, 9, 1-11. [CrossRef]

28. Shen, W.; Shi, J.; Chen, H.; Gu, J.; Zhu, Y.; Dong, X. Synthesis and CO oxidation catalytic character of high surface area ruthenium dioxide replicated by cubic mesoporous silica. Chem. Lett. 2005, 34, 390-391. [CrossRef]

29. Ryan, J.V.; Berry, A.D.; Anderson, M.L.; Long, J.W.; Stroud, R.M.; Cepak, V.M.; Browning, V.M.; Rolison, D.R.; Merzbacher, C.I. Electronic connection to the interior of a mesoporous insulator with nanowires of crystalline $\mathrm{RuO}_{2}$. Nature 2000, 406, 169-172. [CrossRef]

30. Viswanathamurthi, P.; Bhattarai, N.; Kim, C.K.; Kim, H.Y.; Lee, D.R. Ruthenium doped $\mathrm{TiO}_{2}$ fibers by electrospinning. Inorg. Chem. Commun. 2004, 7, 679-682. [CrossRef]

31. Browne, M.P.; Nolan, H.; Duesberg, G.S.; Colavita, P.E.; Lyons, M.E.G. Low-overpotential high-activity mixed manganese and ruthenium oxide electrocatalysts for oxygen evolution reaction in alkaline media. ACS Catal. 2016, 6, 2408-2415. [CrossRef]

32. Gustafson, K.P.J.; Shatskiy, A.; Verho, O.; Kärkäs, M.D.; Schluschass, B.; Tai, C.-W.; Åkermark, B.; Bäckvall, J.-E.; Johnston, E.V. Water oxidation mediated by ruthenium oxide nanoparticles supported on siliceous mesocellular foam. Catal. Sci. Technol. 2017, 7, 293-299.

33. Gao, L.; Zhuang, J.; Nie, L.; Zhang, J.; Zhang, Y.; Gu, N.; Wang, T.; Feng, J.; Yang, D.; Perrett, S.; et al. Intrinsic peroxidase-like activity of ferromagnetic nanoparticles. Nat. Nanotechnol. 2007, 2, 577-583. [CrossRef] [PubMed] 
34. Chen, X.; Zhou, X.; Hu, J. Pt-DNA complexes as peroxidase mimetics and their applications in colorimetric detection of $\mathrm{H}_{2} \mathrm{O}_{2}$ and glucose. Anal. Methods 2012, 4, 2183-2187. [CrossRef]

35. Chen, T.; Tian, L.; Chen, Y.; Liu, B.; Zhang, J. A facile one-pot synthesis of $\mathrm{Au} / \mathrm{Cu}_{2} \mathrm{O}$ nanocomposites for nonenzymatic detection of hydrogen peroxide. Nanoscale Res. Lett. 2015, 10, 935. [CrossRef] [PubMed]

36. Guan, J.; Peng, J.; Jin, X. Synthesis of copper sulfide nanorods as peroxidase mimics for the colorimetric detection of hydrogen peroxide. Anal. Methods 2015, 7, 5454-5461. [CrossRef]

37. Wei, Y.; Zhang, Y.; Liu, Z.; Guo, M. A Novel Profluorescent Probe for detecting oxidative stress induced by metal and $\mathrm{H}_{2} \mathrm{O}_{2}$ in living cells. Chem. Commun. 2010, 46, 4472-4474. [CrossRef]

38. Dickinson, B.C.; Chang, C.J. A targetable fluorescent probe for imaging hydrogen peroxide in the mitochondria of living cells. J. Am. Chem. Soc. 2008, 130, 9638-9639. [CrossRef]

39. Finkel, T.; Serrano, M.; Blasco, M.A. The common biology of cancer and ageing. Nature 2007, 448, 767-774. [CrossRef]

40. Bard, A.J.; Faulkner, L.R. Electrochemical Methods: Fundamentals and Applications, 2nd ed.; John Wiley \& Sons: New York, NY, USA, 2001.

41. Stoerzinger, K.A.; Qiao, L.; Biegalski, M.D.; Shao-Horn, Y. Orientation-dependent oxygen evolution activities of rutile $\mathrm{IrO}_{2}$ and $\mathrm{RuO}_{2}$. J. Phys. Chem. Lett. 2014, 5, 1636-1641. [CrossRef]

42. AlShehri, S.M.; Ahmed, J.; Ahamad, T.; Arunachalam, P.; Ahmad, T.; Khan, A. Bifunctional electro-catalytic performances of $\mathrm{CoWO}_{4}$ nanocubes for water redox reactions (OER/ORR). RSC Adv. 2017, 7, 45615-45623. [CrossRef]

43. Jiang, R.; Tran, D.T.; Li, J.; Chu, D. Ru@RuO 2 core-shell nanorods: A highly active and stable bifunctional catalyst for oxygen evolution and hydrogen evolution reactions. Energy Environ. Mater. 2019, 2, 201-208. [CrossRef]

44. Bhowmik, T.; Kundu, M.K.; Barman, S. Growth of one-dimensional $\mathrm{RuO}_{2}$ nanowires on g-carbon nitride: An active and stable bifunctional electrocatalyst for hydrogen and oxygen evolution reactions at all $\mathrm{pH}$ values. ACS Appl. Mater. Inter. 2016, 8, 28678-28688. [CrossRef] [PubMed]

45. Cherevko, S.; Geiger, S.; Kasian, O.; Kulyk, N.; Grote, J.-P.; Savan, A.; Shrestha, B.R.; Merzlikin, S.; Breitbach, B.; Ludwig, A.; et al. Oxygen and hydrogen evolution reactions on $\mathrm{Ru}, \mathrm{RuO}_{2}$, $\mathrm{Ir}$, and $\mathrm{IrO}_{2}$ thin film electrodes in acidic and alkaline electrolytes: A comparative study on activity and stability. Catal. Today 2016, 262, 170-180. [CrossRef]

46. Farooq, U.; Phul, P.; Alshehri, S.M.; Ahmed, J.; Ahmad, T. Electrocatalytic and enhanced photocatalytic applications of sodium niobate nanoparticles developed by citrate precursor route. Sci. Rep. 2019, 9, 4488. [CrossRef]

47. Ahmed, J.; Ubaidullah, M.; Ahmad, T.; Alhokbany, N.; Alshehri, S.M. Synthesis of graphite oxide/cobalt molybdenum oxide hybrid nanosheets for enhanced electrochemical performances in supercapacitors and OER. ChemElectroChem 2019, 6, 2524-2530. [CrossRef]

48. Bos, E.S.; van der Doelen, A.A.; van Rooy, N.; Schuurs, A.H.W.M. 3,3',5,5'-etramethylbenzidine as an ames test negative chromogen for horse-radish peroxidase in enzyme immunoassay. J. Immunoass. 1981, 2, 187-204. [CrossRef]

49. Zhou, B.; Wang, J.; Guo, Z.; Tan, H.; Zhu, X. A simple colorimetric method for determination of hydrogen peroxide in plant tissues. Plant Growth Regul. 2006, 49, 113-118. [CrossRef]

(C) 2020 by the authors. Licensee MDPI, Basel, Switzerland. This article is an open access article distributed under the terms and conditions of the Creative Commons Attribution (CC BY) license (http://creativecommons.org/licenses/by/4.0/). 